\title{
The Anti-proliferative Ability of the Ethanol Extract of Annona muricata Leaves on Widr Cancer Cells
}

\author{
Yoni Astuti ${ }^{1 *}$, Agus Suharto ${ }^{2}$, Sabtanti Harimurti ${ }^{3}$, Wahyu Joko Priambodo ${ }^{4}$ \\ ${ }^{1}$ Department of Biochemistry, School of Medicine, Faculty of Medicine and Health Sciences, Universitas Muhammadiyah \\ Yogyakarta, Yogyakarta, Indonesia \\ 2 Department of Pathology Anatomi, School of Medicine, Faculty of Medicine and Health Sciences, Universitas \\ Muhammadiyah Yogyakarta, Yogyakarta, Indonesia \\ 3Pharmacy School, , Faculty of Medicine and Health Sciences, Universitas Muhammadiyah Yogyakarta, Yogyakarta, \\ Indonesia \\ ${ }^{4}$ Medicinal Plant and Traditional Medicine Research and Development Center, Tawangmangu, Surakarta, Indonesia
}

\begin{abstract}
DATE OF ARTICLE:
Received: 06 Nov 2021

Reviewed: 20 Dec 2021

Revised: 02 Jan 2022

Accepted: 18 Jan 2022

CORRESPONDENCE:

yonia@umy.ac.id

DOI:

10.18196/mmjkk.v21i2.13345

TYPE OF ARTICLE:

Research

Abstract: Soursop (Annona muricata) leaves are widely distributed in the tropics, including Indonesia. Soursop leaves are known to contain many anticancer compounds. Research from various countries using soursop leaves provides a different picture of the size of the dose. This research is qualitative research to determine the antiproliferative properties of soursop leaf alcohol extract on Widr cells as a model of colon cancer cells. The soursop leaves were provided from Medicinal Plant and Traditional Medicine Research and Development Center inTawangmangu. The thinlayer chromatography method was used to analyze the profile of soursop leaf extract. Microtetrazolium (MTT) proliferation test was used to analyze antiproliferative effects. The result showed that the essence quality of soursop leaves in aquoes solution was (20.65 \pm 0.07$) \%$; in ethanol solution was $(19.22 \pm 0.34) \%$. The profile of ingredient soursop leaves was more visible in 366 than in 254. The ethanol extract of soursop leaves showed an antiproliferation effect at IC 50 at a dose $450 \mathrm{ug} / \mathrm{ml}$. In conclusion, the ethanolic extract of Annona muricata showed antiproliferative properties at a dose of $450 \mathrm{ug} / \mathrm{ml}$ and having a half cell dose of IC 50 .
\end{abstract}

Keywords: Antiproliferative; Annona muricata leaves; Widr cancer cell

\section{INTRODUCTION}

Annona muricata L, known as Graviola, soursop, or corossol, belongs to the Annonaceae family. The tree's shape is small to medium, which is widespread and comes from Central America. ${ }^{1,2}$ Annona is a tropical tree with heart-like and edible, and widespread in most tropical countries. All parts of the A. muricata tree can be included in twigs, leaves, roots, fruits, and seeds. It is used for various treatments in the tropics. Generally, fruit and fruit juices are taken to get rid of worms and parasites, cool fever, increase breast milk after childbirth, and so on astringent for diarrhea and dysentery. ${ }^{3,4}$

Phytochemical investigation of the leaf of A. muricata showed the presence of alkaloids, ${ }^{3}$ essential oils, ${ }^{5}$ and acetogenins. ${ }^{6}$ These acetogenins were demonstrated to be selectively toxic against various types of cancerous cells without harming healthy cells. ${ }^{6}$ Acetogenin 1 was reported to exhibit cytotoxic activities against the human pancreatic tumor cell line (PACA-2), human prostate adenocarcinoma (PC-3), and human lung carcinoma (A-549), while Acetogenin 2 was reported to exhibit cytotoxicity against human hepatoma carcinoma cell line (Hep G2).7,8 Seven isoquinoline alkaloids were isolated from the leaves, including reticuline, coclaurine, coreximine, atherosperminine, stepharine, anomurine, annomuricine root, and stem barks of $A$. muricata. ${ }^{9,10}$ The essential oil of the fresh fruit pulp of $A$. muricata contains 2-hexenoic acid methyl ester (23.9\%), 2-hexenoic acid ethyl ester (8.6\%), 2-octanoic acid methyl ester (5.4\%), 2-butenoic acid methyl ester (2.4\%), $\beta$-caryophyllene (12.7\%), 1,8- cineole (9.9\%), linalool (7.8\%), a-terpineol (2.8\%), linalyl propionate (2.2\%), and calarence (2.2\%). ${ }^{11,12}$ Therefore, the researchers attempted to investigate the growth-inhibitory and 
apoptotic effects of extracts from leaf, twigs, and roots from A. muricata against Human promyelocytic leukemia (HL-60 cells).

This study was carried out to explore the antiproliferation of ethanol extract A. muricata from Tawangmangu against Widr cancer cell due to the model of colon cancer as data showed that colon cancer is the third cancer-causing mortality.

\section{MATERIALS AND METHOD}

\section{Preparation for ethanol extract and aquadest extract Annona muricata}

Principally, the sample was extracted with ethanol extract and water-chloroform $\left(\mathrm{CH}_{3} \mathrm{Cl}\right)$, precipitated, and then separated between the filtrate and residue through a filtering process. The extract was obtained through the solvent evaporation process and was applied to calculate the water-soluble extract content.

\section{Determination of water-soluble juice content}

Carefully $5 \mathrm{~g}$ of medicinal plant Simplicia powder was weighed and put in a closed laboratory bottle. $100 \mathrm{~mL}$ of water chloroform was added, then shaken using a shaker for 6 hours. It was set aside for 18 hours, and the entire filtrate was filtered. $20 \mathrm{~mL}$ is taken and put in a porcelain cup; the filtrate was evaporated to dryness, the residue was heated at $105^{\circ} \mathrm{C}$, and was put in a desiccator, frozen, and weighted to a constant weight. The calculation of water-soluble extract content in the sample is:

$$
\%=\frac{\text { Final weight }(\mathrm{g})-\text { Previous weightl }(\mathrm{g})}{5.0 \text { gram }} \times 5 \times 100 \%
$$

Note that the final weight is extracted weight + porcelain cup. The initial weight is the weight of the initial porcelain dish after heating

\section{Determination of ethanol-soluble juice content}

The sample was extracted with $96 \%$ ethanol, precipitated, and then separated between the filtrate and residue through a filtering process; the extract was obtained through the solvent evaporation process, then the data obtained was applied in the formula for calculating the ethanol-soluble extract content.

$$
\%=\frac{\text { Final weight }(\mathrm{g})-\text { Previous weightl }(\mathrm{g})}{5.0 \text { gram }} \times 5 \times 100 \%
$$

Note that the final weight is extracted weight + porcelain cup, and the initial weight is the weight of the initial porcelain dish after heating.

\section{Soursop Leaf Profile Analysis}

The sample was 100mg, dissolved with @10ml Ethanol pa, sonicated for 15 minutes; then the sample was set (overnight). Thin Layer Chromatography (TLC) preparation included; 5 microliters of clear parts were spotted on a 60 F254 silica gel plate with Silica plate was eluted in the mobile phase of Chloroform: Methanol = 9:1. The silica plate was dried in the air, followed by a reading with a TLC-Scanner at a wavelength of 254 $\mathrm{nm}, 366 \mathrm{~nm}$, and visible light.

\section{Proliferation assay}

Microtetrazolium was used to calculate the population that had twice the population number of Widr cancer cells. This assay was based on production formazan from the destruction of 3-[4,5dimethylthiazol-2-yl]-2,5 diphenyltetrazolium bromide by succinate tetrazolium.

\section{RESULTS}

Soursop leaf extract content with $\mathrm{CHCL}_{3}$ and ethanol solvent. Anonna leaf simplicia in this study came from Matesih, Tawangmangu, Central Java, Indonesia, a provider of simplicia for research. To compare the levels of Annona leaf extract, two solvents were used, namely aquadest and $96 \%$ ethanol. The quality of the contents of the essence of both can be seen in Table 1 . 


\section{mutiara \\ medika}

Tabel 1. Quality of essence Annona muricata leaves based on the solvents

\begin{tabular}{llllc}
\hline \multirow{2}{*}{ Preparation form } & Solvents & Weight $(\mathrm{G})$ & Level (\%) & Average \\
\hline \multirow{3}{*}{ Powder } & Aquadest $+\mathrm{CHCl3}$ & 2.0004 & 20.70 & $20.65 \pm 0,07$ \\
& & 2.0003 & 20.60 & \\
& \multirow{2}{*}{ Ethanol 96\% } & 2.0006 & 19.47 & $19.22 \pm 0,34$ \\
\hline
\end{tabular}

In the treatment using aquadest, the starch extract was higher than ethanol. However, the use of aqua dest did not last long. The risk of exposure to fungi due to high water concentrations was a consideration for using aqua dest as a solvent for Annona leaf extract. In alcohol solvent, the soluble starch was more durable and resistant to fungal contamination. Thus, in future research, alcohol extract is used.

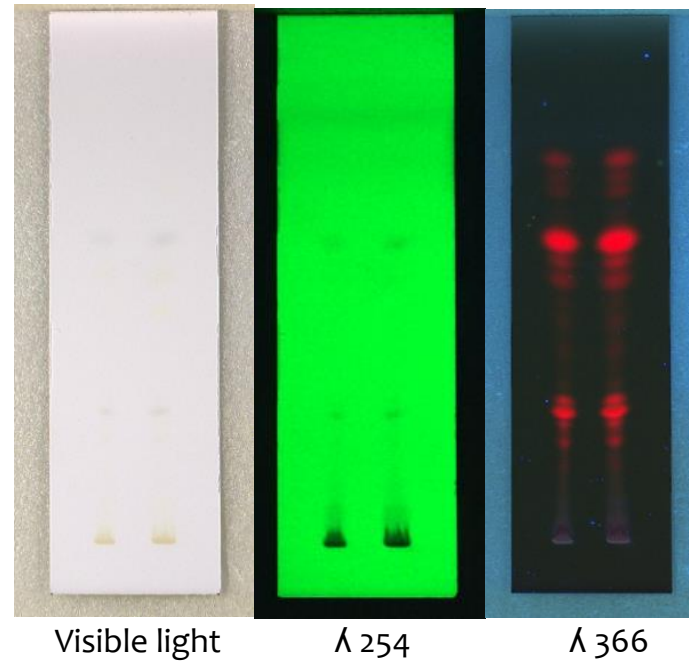

Figure 1. Profile of ethanol extract of soursop leaves by using TLC

TLC profiling is shown in Figure 1. In use with a wavelength of 366, the essence is more clearly depicted than at a wavelength of 254. In alcoholic solvents, the starch extract is lower than that of aquadest solvents. Chromatogram profiling showed a higher peak in $\Lambda 366$ than $\Lambda 254$, as shown in Figure 2 and Figure 3. $\wedge 366$ showed more peaks than $\wedge 254$, so more substances appeared using $\wedge 366$.

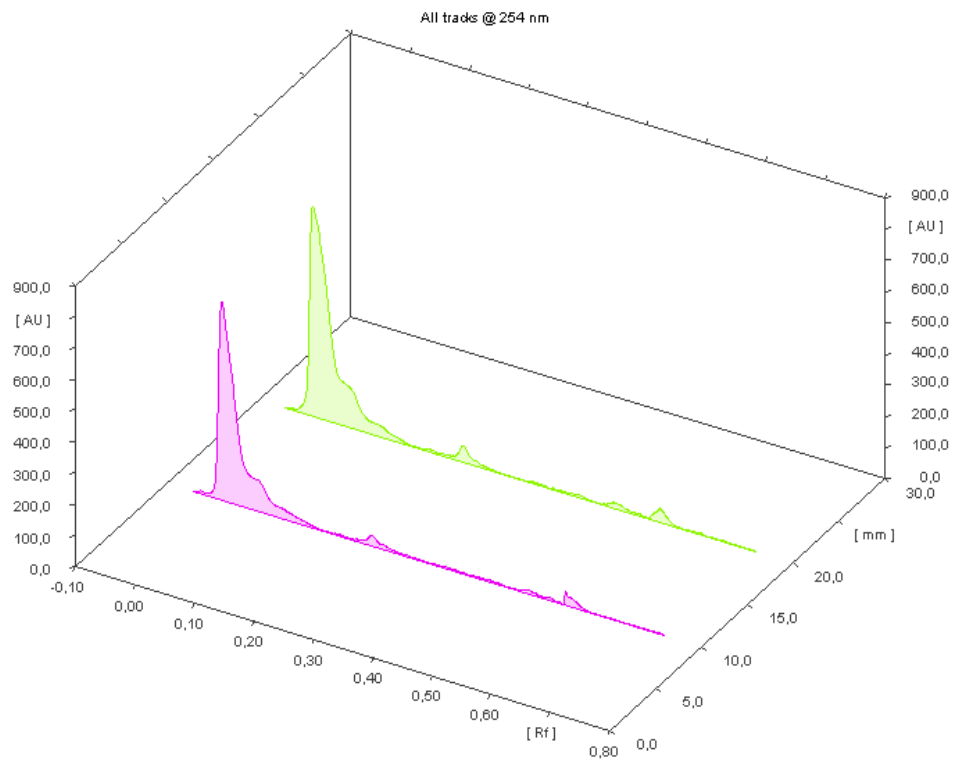

Figure 2. Chromatogram Profile (TLC) ethanol extract of soursop leaves on the wavelength of 254 


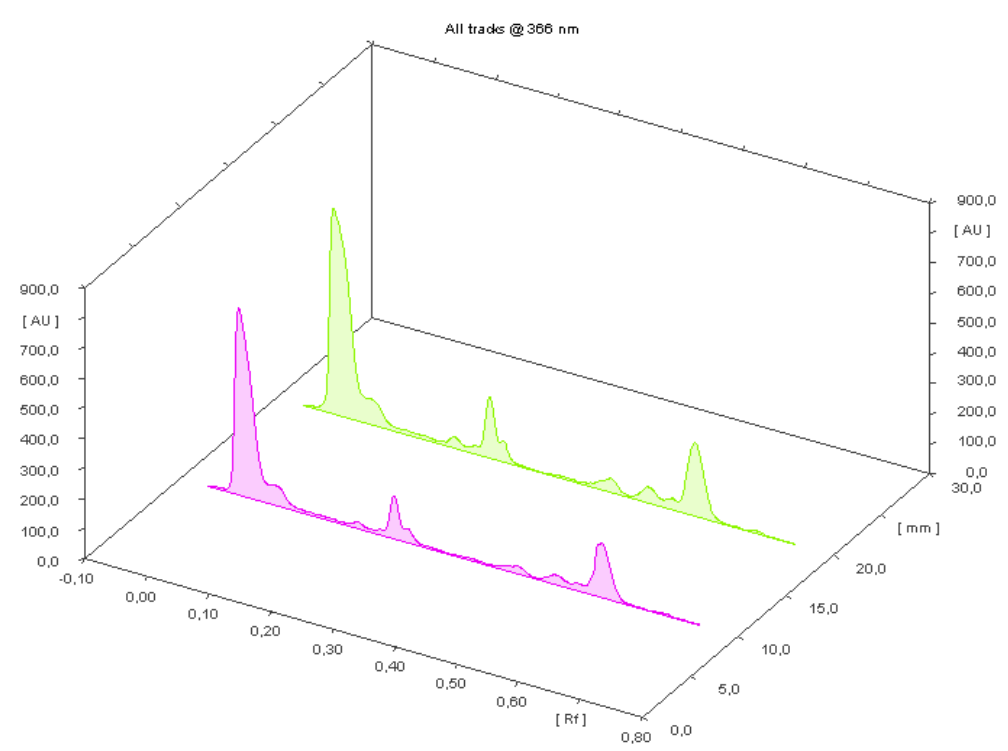

Figure 3. Chromatogram Profile (TLC) ethanol extract of soursop leaves on the wavelength of 366

Proliferation of WiDr Cancer Cell during Induction with Serial dose of Extract Ethanol Soursop Leaves from Tawangmangu. Figure 4 demonstrates the equation based on population cells in a dose-dependent manner. The equation was $\mathrm{Y}=-0.1087 \mathrm{X}+98.921$ with $\mathrm{R}^{2}=0.7934$. The half population after induced $E E C L$ was around $450 \mathrm{ug} / \mathrm{ml}$. Meanwhile, the serial dose showed the proliferation capacity reduction in Table 2 . Antiproliferation dose is the dose that increases the population number to be twice of population number.

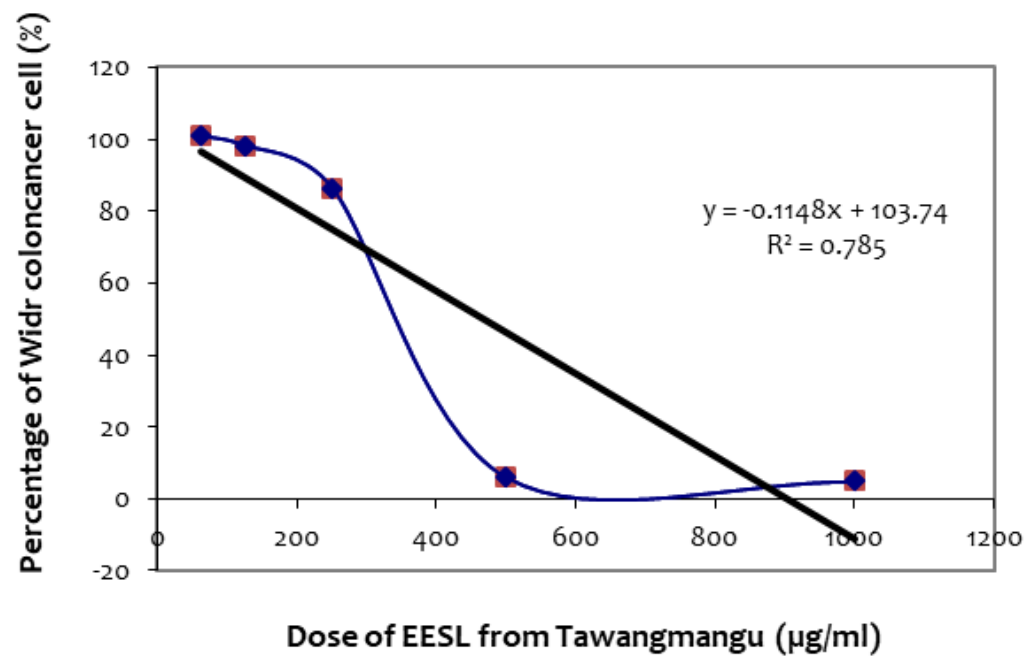

Figure 4. Linear regression of percentage Widr cell population based on a dose of ethanol extract of soursop leaves

Tabel 2. Antiproliferation dose of ethanol extract of soursop leaves on population Widr cell

\begin{tabular}{ll} 
Dose $(\mathrm{ug} / \mathrm{ml})$ & Widr cell population \\
\hline 450 & 0.5 IC 50 \\
225 & $0.25 \mathrm{IC} 50$ \\
112.5 & 0.125 IC50 \\
66.25 & 0.0625 IC 50 \\
33.125 & 0.03125 IC 50 \\
\hline
\end{tabular}




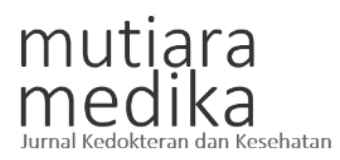

\section{DISCUSSION}

The essence of ethanolic and aqueous extract on soursop leaf in this study showed that polar agent was higher than non-polar agent as shown in table 1. A previous report showed that the primer and secondary metabolites contained polysaccharide, protein, Glikosaponin, alkaloids, saponins, terpenoids, flavonoids, and coumarins lactones, anthraquinones, tannins, cardiac glycosides, phenols and phytosterols, and most were polar agents. ${ }^{13,14}$ The presence of alkanes, ester, aromatic ring, and hydroxyl groups constructed the annonaceous acetogenins from soursop. ${ }^{12}$

This study showed that the Leaf of A. muricata exhibited antiproliferative effects at the WiDr Cancer cell. The effect was dose-dependent manner as shown in table 2. The antiproliferative effect was also shown in HL-60 cells by inducing loss of cell viability, morphology changes, loss of membrane mitochondrial potential, and $\mathrm{Go} / \mathrm{G}_{1}$ phase cell arrest. It confirmed the potential of $A$. muricata as an agent of chemotherapeutic and cytostatic activity in HL-60 cells. The values of IC50 of the extract after 48 h was between 6-12 $\mathrm{gg} / \mathrm{mL}$, which was lower than $20 \mu \mathrm{g} / \mathrm{mL} .^{10,15}$ In line with this finding, ethanol extract A. muricata from Tawangmangu exhibits antiproliferation on Widr cancer cells. It showed the $1 / 2$ IC 50, especially in dose $450,05 \mathrm{ug} / \mathrm{ml}$. In this study, the value of IC 50 was much bigger than the previous study due to the different locations that influenced the quality of essence of soursop leaf.

Meanwhile, on HepG2 cells of a liver cancer cell line, the incubation during 24 and $48 \mathrm{~h}$ showed LD50 values of Annona muricata, which was approximately 180 and $80 \mu \mathrm{g} / \mathrm{ml}$, respectively. ${ }^{16}$ Proliferating cells had the choice of Go phase. Entering the Go phase of $\mathrm{G} 1$ is an important choice in cell development. In in vitro research, adequate growth factors are needed to enter $G 1$ to the $S$ phase. This point is also called the restriction point. When the cellular environment is insufficient to pass the restriction point, it will return to the Go phase. ${ }^{17}$ Soursop leaf also showed the ability in reducing index proliferation of breast cancer in rat. ${ }^{18}$ Furthermore, the ethanol extract of Annona had antiproliferative properties. However, it still requires further investigation to use this extract as an alternative or preventive activity. Besides, the opportunity to use raw extract due to the availability of this plant in our near area, such as in our yard, still needs further investigation. The kind of extract sample as infusa or as a powder is possible to use, especially to prevent cancer, and alternatively, to reduce the metastasis of malignancies.

\section{CONCLUSION}

Ethanol extract of Annona muricata leaves had antiproliferative potential in Widr cells. The dose of antiproliferative ability to inhibit half the Widr cell population was $450 \mathrm{ug} / \mathrm{ml}$.

\section{ACKNOWLEDGEMENT}

The researchers would like to thank DRPM (DIKTI) for providing grants for this research (Number 3279.4/LL5/PG/2021).

\section{CONFLICT OF INTEREST}

There is no conflict of interest in this research.

\section{REFERENCES}

1. Wélé A, Zhang Y, Caux C, Brouard JP, Pousset JL, Bodo B. Annomuricatin C, A Novel Cyclohexapeptide from the Seeds of Annona muricata. C R Chimie 2004, 7:981-988. https://doi.org/10.1016/j.crci.2003.12.022

2. Ibrahim AA, Sandhika W, Budipramana VS. The Effect of Annona muricata's Leaf Ethanolic Extract Against the Breast Cancer Cell Line Mcf-7. Jurnal Manajemen Kesehatan Yayasan RS.Dr.Soetomo. April 2020: 6(1): 64 72. https://doi.org/10.29241/jmk.v6i1.289

3. George D, Pamplona R. Encyclopedia of Medical Plants. Editional Safelize Spain 1999, 1:38

4. Foster K, Oyenihi O, Rademan S, Erhabor J, Matsabisa M, Barker J, Langat MK, Kendal-Smith A, and Delgoda AHR. Selective Cytotoxic and Anti-metastatic Activity in DU-145 Prostate Cancer Ceinduced by Annona muricata L. Bark Extract and Phytochemical Annonacin. BMC Complementary Medicine and Therapies. 2020: 20:375

5. Leboeuf M, Cavé A, Bhaumik PK, Mukherjee B, Mukherjee R. The Phytochemistry of the Annonaceae. Phytochem 1982, 21:2783-2813. 
6. Yajid AI, Rahman HS, Pak Kai MW, Wan Zain WZ. Potential Benefits of Annona muricata in Combating Cancer: A Review. Malays J Med Sci. Jan-Feb 2018; 25(1): 5-15. https://doi.org/10.21315/mjms2018.25.1.2

7. Kossouoh C, Moudachirou M, Adjakidje V, Chalchat JC, Figuérédo G. Essential Oil Chemical Composition of Annona muricata L. Leaves from Benin. J Ess Oil Res 2007, 19:307-309. https://doi.org/10.1080/10412905.2007.9699288

8. Chang FR, Liaw CC, Lin CY, Chou CJ, Chiu HF, Wu YC. New Adjacent Bis-tetrahydrofuran Annonaceous Acetogenins from Annona muricata. Planta Med 2003, 69:241-246. https://doi.org/10.1055/s-2003-38485

9. Ragasa CY, Soriano G, Torres OB, Don MJ, and Shen CC. Acetogenins from Annona muricata. Phcog J 2012, 32(4):32-37.

10. Rieser MJ, Kozlowski JF, Wood KV, McLaughlin J. Muricatacin: A Simple Biologically Active Acetogenin Derivative from the Seeds of Annona muricata (Annonaceae). Tetrahedron Lett. 1991, 32:1137-1140.

11. Sulaiman H, Roslida AH, Fezah O, Tan KL, Tor YS, Tan CI: Chemopreventive Potential of Annona Muricata L Leaves on Chemically-Induced Skin Papillomagenesis in Mice. Asian Pac J Cancer Prev 2012, 13:2532-2533. https://doi.org/10.7314/apicp.2012.13.6.2533

12. Daud NNNNM, Ya'akob H, and Rosdi MNM. Acetogenins of Annona muricata Leaves: Characterization and Potential Anticancer Study. Integrative Cancer Science Therapy. 2016:3(4): 543-551. https://doi.org/10.15761/ICST.1000202

13. Jirovetz L, Buchbauer G, Ngassoum MB. Essential Oil Compounds of the Annona muricata Fresh Fruit Pulp from Cameroon. J Agric Food Chem 1998, 46:3719-3720.

14. Pieme CA, Khumar SG, Dongmo MS, Moukette BM, Boyoum FF, Yonkeu JN and Saxena AK. Antiproliferative Activity and Induction of Apoptosis by Annona muricata (Annonaceae) Extract on Human Cancer Cells. BMC Complementary and Alternative Medicine (2014), 14:516. https://doi.org/10.1186/1472-6882-14-516

15. KueteV, Dzotam JK, Voukeng IK, Fankam AG and Efferth T. Cytotoxicity of Methanol Extracts of Annona muricata, Passiflora edulis and Nine Other Cameroonian Medicinal Plants towards Multi-factorial Drugresistant Cancer Cell Lines . SpringerPlus. 2016:5:1666 Pp; 1-12

16. Yang H, Liu N and Lee S. Ethanol Extract of Annona muricata. L Induces Liver Cancer Cell Apoptosis through ROS Pathway. Biomed. EO Pharmacol. J. 2016:9(3):919-925. https://dx.doi.org/10.13005/bpj/1030

17. M-Othman L, K-Hassan AK, Elbaky AEB, and Mahmoud MA. Anticancer Effect of the Ethanol Extract of Annona muricata L. Leaves and Fruit in Cancer Induced Mice. Int'l of Advanced Biochemistry Research 2018; 2(1): 25-29. https://doi.org/10.33545/26174693.2018.v2.i1a.12

18. Sulistyoningrum E, Rachmani EPN, Baroroh HN, and Rujito L. Annona muricata Leaves Extract Reduce Proliferative Indexes and Improve Histological Changes in Rat's Breast Cancer. Journal of Applied Pharmaceutical Science. 2017:7(01):149-155. https://doi.org/10.7324/JAPS.2017.70120 